\title{
Downregulation of the CCAAT-Enhancer Binding Protein $\beta$ in $\triangle$ FosB Transgenic Mice and by Electroconvulsive Seizures
}

\author{
Jingshan Chen',3, Samuel S Newton', Ling Zeng', David H Adams', Anthoni L Dow', Torsten M Madsen', \\ Eric J Nestler ${ }^{2}$ and Ronald S Duman*, I \\ 'Division of Molecular Psychiatry, Department of Psychiatry, Yale University School of Medicine, New Haven, CT, USA; ${ }^{2}$ Department of Psychiatry \\ and Center for Basic Neuroscience, The University of Texas Southwestern Medical Center, Dallas, TX, USA; ${ }^{3}$ Clinical Brain Disorders Branch, \\ NIMH, Bethesda, MD, USA
}

\begin{abstract}
Previous studies demonstrate that chronic, but not acute electroconvulsive seizures (ECS), increases levels of $\Delta$ FosB, a long-lasting transcription factor, in the hippocampus, and this effect correlates with the slow onset and long-lasting clinical effects of antidepressant treatment. To understand how $\Delta$ FosB mediates long-term plasticity in the hippocampus, we analyzed the gene expression profile of inducible transgenic mice expressing $\Delta$ FosB with a highly sensitive microarray assay and a customized computer analysis program. The CCAAT-enhancing binding protein- $\beta$ (C/EBP $\beta$ ) was identified as one of the genes downregulated by $\Delta$ FosB in the hippocampus. The downregulation of $\mathrm{C} / \mathrm{EBP} \beta$ in the inducible $\triangle \mathrm{FosB}$ transgenic mice was confirmed by other quantitative assays including real-time RT-PCR and low density dot blotting. Analysis of the C/EBP $\beta$ expression in the hippocampus of rats treated with ECS revealed that the C/EBP $\beta$ mRNA was also downregulated by chronic, but not acute ECS administration, the most effective treatment for depression. Given the reported role of $\mathrm{C} / \mathrm{EBP} \beta$ in behavioral conditioning models, it is possible that the $\triangle$ FosB-mediated downregulation of $\mathrm{C} / \mathrm{EBP} \beta$ in the hippocampus may be a molecular mechanism by which antidepressants alleviate some of the symptoms of depressed patients. Neuropsychopharmacology (2004) 29, 23-31, advance online publication, 8 October 2003; doi:I 0.1038/sj.npp. 1300289
\end{abstract}

Keywords: antidepressant; $\triangle \mathrm{FosB}$; C/EBP $\beta$; hippocampus; microarray; memory

\section{INTRODUCTION}

Electroconvulsive seizure (ECS) therapy is one of the most effective antidepressants and the treatment of choice for depressed patients who do not respond to chemical medications (Franco-Bronson, 1996; Stewart and Reid, 2000; Duman, 2002; Nestler et al, 2002). Although electroconvulsive therapy has been used for many years, the molecular mechanisms underlying the efficacy of this treatment remain largely unknown. Since repeated administration of ECS is required for its full clinical efficacy, gradual neural adaptive changes in response to repeated treatment may underlie the molecular mechanism of its antidepressant action (Duman et al, 1997, 2000; Nestler et al, 2002). Another important feature of ECS treatment is that its antidepressant effect can last for a relatively long period of time after the final treatment, which suggests that the therapeutic changes are relatively stable. Therefore, transcription factors and regulation of neural gene expression

\footnotetext{
*Correspondence: Dr RS Duman, Division of Molecular Psychiatry, Department of Psychiatry, Yale University School of Medicine, 34 Park Street, New Haven, CT 06508, USA, Tel: + I 203974 7726, Fax: + I 203974 7724, E-mail: ronald.duman@yale.edu

Received 20 December 2002; revised 23 June 2003; accepted 01 July 2003

Online publication: II July 2003 at http://www.acnp.org/citations/ NPP07| | 0302483/default.pdf
}

may play an important role in the mood-elevating effects of chronic ECS treatment.

One transcription factor implicated in the actions of antidepressant treatment is the cAMP response elementbinding protein (CREB) (Nibuya et al, 1996; Manji and Duman, 2001). Levels of CREB and of CREB-mediated transcription are increased in the hippocampus and cerebral cortex by chronic antidepressant treatments, including ECS (Nibuya et al, 1996; Thome et al, 2000; Koch et al, 2002; Nakagawa et al, 2002). This upregulation of CREB may help restore normal cAMP signaling in these brain regions, whereas abnormally low levels of CREB in depressed patients have been reported (Dowlatshahi et al, 1998; D'Sa and Duman, 2002). Overexpression of CREB in the rat hippocampus by viral gene transfer results in antidepressant-like effects in models of depression (ie the forced swim and learned helplessness tests), which supports a role for CREB in the action of antidepressants (Chen et al, 2001). One of the potential target genes regulated by CREB is brain-derived neurotrophic factor (BDNF). Chronic antidepressant treatment increases BDNF expression in the hippocampus (Nibuya et al, 1995, 1996), and this induction is absent in mice lacking the CREB gene (Conti et al, 2002). Antidepressant induction of BDNF could then have palliative effects on several aspects of the hippocampal function and ease certain symptoms of depression. 
Another transcription factor that has been implicated in the action of antidepressants is $\Delta$ FosB. The expression of $\Delta \mathrm{FosB}$ is gradually induced in the hippocampus and cerebral cortex by chronic administration of antidepressants, most notably by chronic ECS (Hope et al, 1994; Nestler et al, 1999; Nestler, 2001). $\Delta$ FosB is an alternatively spliced variant of the fos $B$ gene. Like c-Fos, $\Delta$ FosB forms heterodimers with Jun proteins, mainly JunD, to form active activator protein-1 (AP-1) complexes, which then bind to $\mathrm{AP}-1$ sites in the promoter regions of many neural genes (Chen et al, 2000). $\Delta$ FosB lacks a portion of the C-terminus, which is the major transactivation domain of full-length FosB (Nakabeppu et al, 1993). Therefore, $\Delta$ FosB may be a weak transcriptional activator and in some cases may function as a transcriptional repressor (Nakabeppu and Nathans, 1991). Several downstream target genes for $\Delta$ FosB have been identified to date, including NMDAR1, GluR2, cyclin-dependent kinase-5 (Cdk5), and NF- $\kappa \mathrm{B}$ (Hiroi et al, 1998; Kelz et al, 1999; Chen et al, 2000; Ang et al, 2001).

$\Delta$ FosB is unique with respect to its temporal properties of expression. Two major $\triangle \mathrm{FosB}$ isoforms, of 35 and $37 \mathrm{kDa}$ proteins, are generated by chronic ECS treatment from a single open reading frame, presumably by post-translational modification (Chen et al, 1997). These $\Delta$ FosB isoforms are highly stable proteins, which means that they gradually accumulate in neurons over the course of repeated ECS treatment (Hope et al, 1994). The gradual induction of $\Delta$ FosB, and its persistence after a course of chronic treatment correlate with the slow onset and long-lasting effects of antidepressant treatments, which suggests that $\Delta$ FosB may be an important mediator of antidepressant action. Understanding how $\triangle \mathrm{FosB}$ produces its functional effects could, therefore, provide an insight into the molecular mechanisms of antidepressant treatments.

In this study, we searched for downstream target genes for $\triangle \mathrm{FosB}$ using DNA microarrays to analyze the gene expression profiles in the hippocampus of inducible transgenic mice that overexpress $\Delta$ FosB. The CCAATenhancing binding protein- $\beta(\mathrm{C} / \mathrm{EBP} \beta)$ was identified as a target gene downregulated by $\Delta$ FosB. The downregulation of $\mathrm{C} / \mathrm{EBP} \beta$ was confirmed in the hippocampus of rats treated with chronic ECS treatment. The possible role of C/ $\operatorname{EBP} \beta$ in the actions of ECS and antidepressant treatment is discussed.

\section{MATERIALS AND METHODS}

\section{Transgenic Mice}

Inducible transgenic mice were developed as described previously (Chen et al, 1998). Male 10-week-old bitransgenic $11 \mathrm{~A}$ mice that express $\Delta \mathrm{FosB}$ in an inducible and brain region-specific manner (including the hippocampus), were used in these studies (Kelz et al, 1999). The mice were conceived and raised on doxycycline $(100 \mu \mathrm{g} / \mathrm{ml})$ in the drinking water to suppress $\Delta$ FosB expression completely (Chen et al, 1998). Half of the littermates were removed from doxycycline at 3-4 weeks of age and were used 6 weeks later, at which time $\Delta \mathrm{FosB}$ expression is induced. The hippocampus was removed from decapitated mice by gross dissection. All the transgenic mice used in this study were maintained in strict accordance with the guidelines established by the National Institutes of Health and the Yale institutional animal care committee.

\section{cDNA Microarrays}

Total RNA was isolated from the hippocampus of inducible $\Delta$ FosB transgenic mice using RNAqueous phenol-free total RNA isolation kit (Ambion). A total of $3 \mu \mathrm{g}$ of total RNA was used to generate cDNA probes, which were fluorescently labeled using $\mathrm{Cy} 3$ or $\mathrm{Cy} 5$ dendrimers (Genisphere Inc.), independent of base composition or transcription length. The three-dimensional DNA dendrimer for amplification of signals was named 3DNA technology. The dual cDNA probes were hybridized to $4.6 \mathrm{k}$ mouse cDNA expression arrays produced by the Yale microarray facility. The arrays were hybridized overnight, subjected to posthybridization washes, and then scanned with a GenePix scanner 4000A (Axon Instruments).

\section{Real-Time RT-PCR}

A sensitive Sybr Green-based protocol that can reliably detect two-fold differences in gene expression was used (Newton et al, 2001). Total RNA was isolated from the hippocampus of transgenic mice using the phenol-free total RNA isolation kit, RNAqueous (Ambion, Austin, TX). In all, $40 \mathrm{ng}$ of total RNA was used for cDNA synthesis using oligo dT primers and Sensiscript reverse transcriptase (Qiagen). After first strand cDNA synthesis, RNA was degraded by $\mathrm{NaOH}$ treatment, followed by precipitation of the cDNA using pellet paint coprecipitant (Novagen). The pellet was resuspended in $20 \mu \mathrm{l}$ nuclease-free water and $1 \mu \mathrm{l}$ aliquots were used in each PCR reaction, assembled using the Quantitect PCR kit (Qiagen) and primers specific for C/EBP $\beta$ or cyclophilin. PCR products were amplified in the SmartCycler real-time PCR machine (Cepheid) followed by melt curve analysis and gel electrophoresis to verify specificity and purity of product. All the $\mathrm{C} / \mathrm{EBP} \beta$ data were normalized to the housekeeping gene, cyclophilin.

\section{C/EBP $\beta$ cDNA Dot Blot}

C/EBP $\beta$ and C/EBPa were PCR amplified from whole rat brain cDNA using gene-specific primers. The PCR products were then spotted in duplicate on Nylon membrane (Hybond + , Amersham) in $100 \mathrm{mM} \mathrm{NaOH}$ buffer using a robotic microarrayer (Omnigrid, GeneMachines). Radiolabeled $\left(\mathrm{P}^{33}\right)$ cDNA probes were generated from total hippocampal RNA of the hippocampus of mice expressing $\Delta$ FosB or controls housed with doxycycline in the water and not expressing $\triangle$ FosB. Filters were hybridized overnight in Microhyb buffer (ResGen), washed at high stringency, and exposed to phosphorimager screens. Spot intensity was quantified using Optiquant software (Packard Instruments) and data analysis was performed with Microsoft Excel.

\section{ECS Treatment}

Male Sprague-Dawley rats (initial weight, $140-260 \mathrm{~g}$; Charles River) were used for all experiments. ECS was administered, as before (Winston et al, 1990), via earclip electrodes $(55 \mathrm{~mA}, 0.3 \mathrm{~s})$. Chronic animals received a single 
ECS daily for 10 days. The control animals received chronic sham treatment, in which electrodes were clipped onto the rats' ears but no current was applied. For chronic treatment, rats were killed $18 \mathrm{~h}$ after the last of 10 daily ECS treatments. Prior sham treatments were used to reduce the effects of stress. The hippocampus was obtained by gross dissection.

\section{Western Blotting}

Western blotting was performed as described previously (Hope et al, 1994). Hippocampus was homogenized in EMSA buffer, aliquots (containing $50 \mu \mathrm{g}$ of protein) were applied to a $10 \%$ acrylamide $/ 0.27 \% N, N$-methylenebisacrylamide resolving gel for SDS-PAGE overnight at $75 \mathrm{~V}$, and then electrotransferred to nitrocellulose at $200 \mathrm{~mA}$ for $3 \mathrm{~h}$. Blots were blocked with four $15 \mathrm{~min}$ changes of $2 \%$ nonfat dry milk in PBS-Tween (PBS containing $0.1 \%$ Tween 20) and then incubated overnight on a shaker at $4{ }^{\circ} \mathrm{C}$ in a $1: 4000$ dilution of anti-Fos-related antigen (FRA) antibody (kindly provided by $\mathrm{Dr}$ Michael Iadarola, National Institute of Dental Research, NIH) in blocking buffer with $0.05 \%$ sodium azide. After washing four times for $15 \mathrm{~min}$ each in blocking buffer, blots were incubated for $2 \mathrm{~h}$ in a $1: 4000$ dilution of goat anti-rabbit antibody conjugated to horseradish peroxidase (Vector Laboratories, Burlingame, CA) in blocking buffer. The blots were washed eight times for 15 min each with PBS-Tween alone, developed with the enhanced chemiluminescence (ECL) system of Amersham (Arlington Heights, IL), and exposed to Hyperfilm-ECL (Amersham) for 5-60 s. For C/EBPb Western blot analysis, homogenates of the hippocampus (in 1\% SDS) were subjected to gel electrophoresis as described above and then blots were incubated with a $1: 400$ dilution of the anti$\mathrm{C} / \mathrm{EBPb}$ antibody (Santa Cruz). After washing, the blots were incubated in a 1:5000 dilution of goat anti-rabbit antibody conjugated to horseradish peroxidase. Relative levels of $\triangle \mathrm{FosB}$ and $\mathrm{C} / \mathrm{EBPb}$ immunoreactive bands were quantified by measuring the optical density of specific bands in the film using an NIH image 1.62 analysis system.

\section{Microsoft Excel-Based Macros for Microarray Data Analysis}

Customized software was designed for analysis of microarray data from the DNA microarrays. The software contains several Microsoft excel-based macros. It was used to process single set or multiple sets of data and extract genes that are regulated in the same direction or in the opposite direction. The software was written in Visual Basic.

\section{RESULTS}

\section{DNA Expression Profiling}

To identify the gene targets regulated by $\Delta$ FosB we utilized the tetracycline-inducible transgenic strategy (Figure 1a). In this system tetracycline binds to the tetracycline-transactivator (tTA) and causes a conformational change that blocks the binding of this protein to its promoter and thereby blocks expression of the downstream transgene, in this case $\Delta$ FosB (Chen et al, 1998; Kelz et al, 1999). The neuronspecific enolase promoter was used to drive expression of

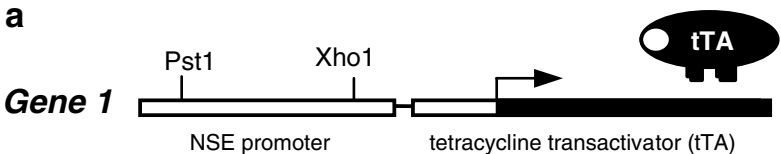

NSE-tTA

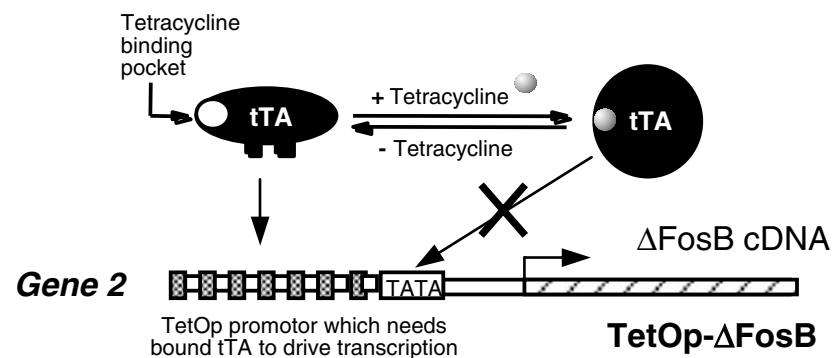

b

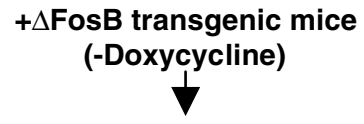

Specific tissue

(Hippocampus)

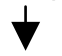

Total RNA

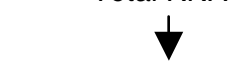

Labeled cDNA probe

(3DNA Reagent, Cy5)

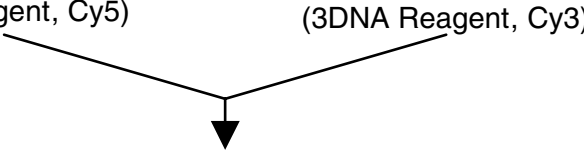

cDNA microarrays

Figure I Identification of downstream target genes regulated by $\Delta$ FosB in the hippocampus of inducible bitransgenic mice: cDNA microarray analysis. (a) Schematic diagram of the tetracycline expression system used for the inducible tissue-specific expression of $\Delta$ FosB (Chen et al, 1998). Gene I encodes the tTA under the control of the neuron-specific enolase (NSE) promoter. Gene 2 encodes $\Delta$ FosB under the control of the tetracycline-responsive promoter with seven tetracycline operators ( $T$ etOp). (b) Strategy for identifying downstream target genes regulated by $\Delta$ FosB in the hippocampus of the inducible transgenic mice. Total RNA was isolated from bitransgenic mice, either expressing or not expressing $\Delta$ FosB. Total RNA samples were used as templates for the synthesis of Cy3- and Cy5-labeled cDNA probes using 3DNA technology. The cDNA probes were hybridized to the arrays, which were then analyzed by the Genepix scanner.

tTA and in the absence of tetracycline, this results in transgene expression largely in forebrain regions, including the hippocampus (Figure 2) (Chen et al, 1998; Kelz et al, 1999). In the present study, mice were conceived and raised on doxycycline, a tetracycline analogue with higher affinity and better brain penetrance, until 3-4 weeks of age. At this point, doxycycline was removed from the drinking water of half of the littermates and the hippocampus was isolated 6 weeks later (approximately 10 weeks of age). Messenger RNA was extracted from the hippocampus of $\Delta$ FosBpositive and -negative mice and used for cDNA synthesis and labeling with $\mathrm{Cy} 5$ and $\mathrm{Cy} 3$ fluorescent dyes, respectively (Figure 1b). One advantage of microarray assays using Cy5 and $\mathrm{Cy} 3$ dye-labeled probes is that two probes can be mixed together and hybridized to a single microarray. 


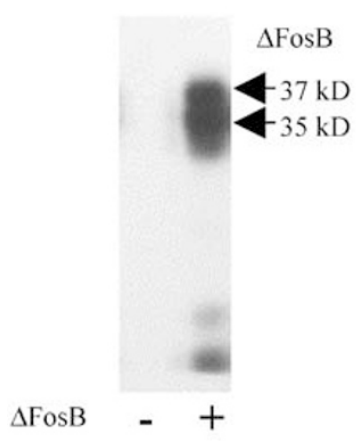

b

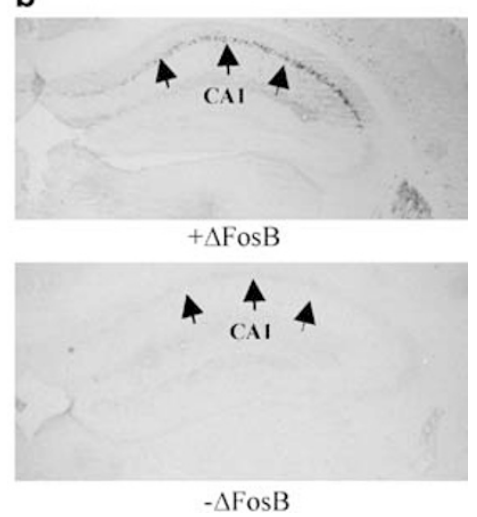

Figure 2 Expression of $\Delta F o s B$ in the hippocampus of bitransgenic mice (a) $\Delta$ FosB immunoreactivity in the hippocampus of the inducible transgenic mice raised in the absence of doxycycline and expressing $\Delta$ FosB $(+\Delta$ FosB $)$ or mice raised in the presence of doxycycline and not expressing $\Delta \mathrm{Fos} B$ $(-\Delta$ FosB $) . \Delta$ FosB was analyzed by Western blotting and a representative immunoblot is shown. Two major isoforms of $\Delta$ FosB were observed at 35 and $37 \mathrm{kDa}$. (b) Immunohistochemistry was conducted on sections from $+\Delta$ FosB and $-\Delta$ FosB mice. Representative images are shown for both controls $(-\Delta$ FosB $)$ and the overexpressing animals $(+\Delta$ FosB $) . \Delta$ FosB is robustly expressed in the CAI pyramidal cell layer of the hippocampus of $+\Delta$ FosB mice but not of controls.

A highly sensitive microarray assay was developed (Newton et al, 2001) using 3DNA technology, which applies three-dimensional DNA dendrimers to enhance the signals by 200 -fold. Using this assay and probes derived from hippocampal RNA samples from inducible $\triangle$ FosB transgenic mice, we detected 3950 signals at $>$ two-fold background levels out of $4592 \mathrm{cDNA}$ spots on a mouse cDNA microarray (Figure 3). To determine the variation of the microarray assay per se, we made Cy3- and Cy5-labeled probes using the same hippocampal RNA sample, mixed the probes, and hybridized them to microarrays. More than $99 \%$ of the detected signals show less than two-fold variation (unpublished data), which suggests that the confidence level of the assay is more than $99 \%$ if two-fold regulation is used as a cutoff value. Since our microarrays were designed by an in-house facility, we developed Microsoft excel-based software written in Visual Basic for analysis of microarray data from the special arrays. Using the software, raw data transfer, elimination of spots with irregular shape and with high background signal, data normalization, statistical analyses, extracting information related to the regulated genes, and clustering of the regulated genes in functional groups were readily accomplished.

\section{Identification of C/EBP $\beta$ as a Downstream Target Gene for $\Delta$ FosB}

We analyzed hippocampal RNA samples from three pairs of inducible transgenic mice. The expression of the $\Delta$ FosB transgene in one of each pair of mice was induced by removal of doxycycline from the drinking water. The other three littermates were maintained on doxycycline, which completely suppresses expression of the transgene and these mice served as controls. Genes regulated by two-fold or more were clustered in six groups: kinases, receptors,
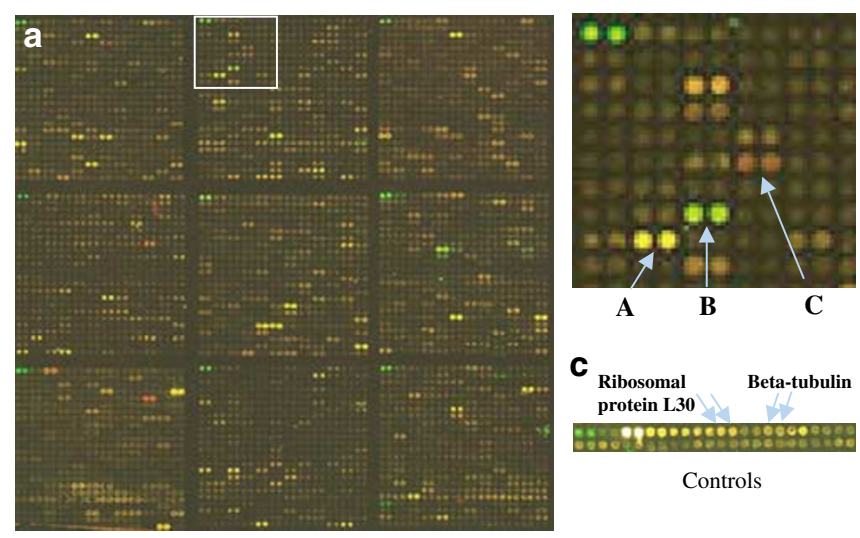

Figure 3 Analysis of gene expression profiles in the hippocampus of inducible transgenic mice expressing $\Delta$ FosB. A representative cDNA microarray image is shown. The cDNA probes were reverse transcribed from the RNA samples isolated from the hippocampus of the inducible transgenic mice expressing or not expressing $\Delta \mathrm{FosB}$ and were labeled with Cy3 (green) and Cy5 (red). The cDNA microarray contained housekeeping gene controls, including ribosomal protein L30 and $\beta$-tubulin. Representative cDNA spots with unchanged (a), increased (b), and decreased (c) expression in the mice expressing $\Delta$ FosB are indicated.

transcription factors, ion channels, phosphatases, and proteases (Table 1). Using this strategy we found only genes that were downregulated by two-fold or greater by the expression of $\Delta$ FosB. No difference was observed when the Cy3 and Cy5 labeling was switched. There were several genes of interest, particularly several different classes of protein kinases. In addition, we found that $\operatorname{C/EBP} \beta$ was downregulated by $73 \%$ in the hippocampus of the inducible transgenic mice expressing $\triangle$ FosB. Since C/EBP $\beta$ is induced in the hippocampus in behavioral learning paradigms and may be required for consolidation of the memory of fearful stimuli (Taubenfeld et al, 2001), it was of interest to characterize further the regulation of $\mathrm{C} / \mathrm{EBP} \beta$ by $\Delta \mathrm{FosB}$ and ECS treatment.

\section{Confirmation of C/EBP $\beta$ Downregulation in the Inducible Transgenic Mice Expressing $\Delta$ FosB}

DNA microarrays represent semiquantitative assays and the results must be confirmed by more quantitative approaches. We isolated RNA samples from the hippocampus of five pairs of inducible $\Delta$ FosB transgenic mice, and analyzed the samples by quantitative real-time RT-PCR (Figure 4). The results showed that the $\mathrm{C} / \mathrm{EBP} \beta$ mRNA is downregulated in the transgenic mice overexpressing $\triangle \mathrm{FosB}$ (Figure 4). To confirm further the regulation of the $\mathrm{C} / \mathrm{EBP} \beta$ expression by $\triangle$ FosB, RNA samples were isolated from the hippocampus of new groups of the inducible $\Delta$ FosB transgenic mice, and subjected to cDNA dot blotting with radioactive isotopelabeled probes for C/EBP $\beta$. The results of the RNA dot blot also demonstrate that $\mathrm{C} / \mathrm{EBP} \beta$ mRNA levels are significantly decreased in the $\Delta$ FosB-positive mice (Figure 5 ). The results of these two independent approaches in separate groups of animals confirm the results of the cDNA microarray and demonstrate that the expression of the C/EBP $\beta$ mRNA is significantly decreased in the mice that overexpress $\Delta$ FosB. 
Table I Genes Regulated in the Hippocampus of FosB-Inducible Transgenic Mice

\begin{tabular}{|c|c|c|c|}
\hline Kinases & ID & Avg. ratio (+ $\Delta$ Fos $B /-\Delta$ Fos $B)$ & SEM \\
\hline Mus musculus Eph- and Elk-related kinase (eek) mRNA, complete cds & Al528730 & 0.451 & 0.017 \\
\hline MEK kinase & Al528522 & 0.45 & 0.011 \\
\hline M. musculus mRNA for MAP kinase-activated protein kinase 2 & Al324228 & 0.381 & 0.031 \\
\hline Protein kinase C, $\theta$ & Al528679 & 0.376 & 0.042 \\
\hline M. musculus type-I transmembrane ER-resident secine/threonine kinase PERK mRNA, complete cds & Al427929 & 0.361 & 0.029 \\
\hline ESTs, weakly similar to Ste-20 related kinase SPAK (M. musculus) & Al429624 & 0.092 & 0.008 \\
\hline \multicolumn{4}{|l|}{ Receptors } \\
\hline Interferon $\gamma$ receptor 2 & Al323654 & 0.373 & 0.014 \\
\hline Leptin receptor & Al323343 & 0.307 & 0.025 \\
\hline \multicolumn{4}{|l|}{ Transcription factors } \\
\hline ESTs, highly similar to transcription factor E2F-4 (M. musculus) & Al427446 & 0.35 & 0.006 \\
\hline CCAAT/enhancer binding protein (C/EBP), $\beta$ & Al323316 & 0.269 & 0.022 \\
\hline \multicolumn{4}{|l|}{ Ion channel } \\
\hline ESTs, highly similar to calcium channel $\beta 4$ subunit (R. norvegicus) & Al4I5454 & 0.371 & 0.033 \\
\hline \multicolumn{4}{|l|}{ Phosphatase } \\
\hline Protein tyrosine phosphatase, receptor type, E & Al323869 & 0.235 & 0.059 \\
\hline \multicolumn{4}{|l|}{ Protease } \\
\hline
\end{tabular}

The cDNA probes were reverse transcribed from the RNA samples isolated from the hippocampus of the inducible transgenic mice expressing FosB or controls not expressing FosB. Hybridizations were conducted as described in Materials and methods. The ratio of the signal in the mice expressing $\Delta$ FosB relative to that in the absence of $\Delta$ FosB was determined. The results are the average of three separate determinations and are the mean \pm SEM.

The difference in percentage decreases detected in the separate experiments is likely due to the individual difference among the transgenic mice as well as the difference among the detection approaches. Although there is a trend for levels of $\mathrm{C} / \operatorname{EBP} \beta$ immunoreactivity to be decreased in the $\Delta$ FosB-positive mice relative to littermate controls, this effect was not significant (Figure 5).

\section{Downregulation of C/EBP $\beta$ in the Hippocampus by Chronic ECS Treatment}

Downregulation of the C/EBP $\beta$ expression by $\Delta$ FosB suggests that $\mathrm{C} / \mathrm{EBP} \beta$ should be similarly downregulated by chronic ECS treatment. To test this possibility, we analyzed the regulation of $\mathrm{C} / \mathrm{EBP} \beta$ in the hippocampus after chronic ECS treatment. The results demonstrate that $\triangle \mathrm{FosB}$, as expected, is increased dramatically in the hippocampus after chronic ECS treatment (Figure 6a). Moreover, there was a corresponding downregulation of $\mathrm{C} / \mathrm{EBP} \beta$ mRNA levels in the hippocampus in response to chronic ECS treatment (Figure 6b). In contrast, acute ECS treatment did not significantly influence the levels of C/EBP $\beta$ mRNA (not shown).

\section{DISCUSSION}

The present study of the molecular actions of $\Delta$ FosB and ECS treatment combines the powers of two sophisticated strategies, inducible transgenic and microarray technologies. The results demonstrate that induction of $\Delta \mathrm{FosB}$ in the hippocampus of inducible transgenic mice, or exposure of normal rats to chronic ECS treatment, downregulates the expression of $\mathrm{C} / \mathrm{EBP} \beta$ in this brain region. Given the reported role of $\mathrm{C} / \operatorname{EBP} \beta$ in fear conditioning (Carew and Sutton, 2001), it is possible that the $\Delta$ FosB-mediated downregulation of $\mathrm{C} / \mathrm{EBP} \beta$ in the hippocampus may be a molecular mechanism by which antidepressants alleviate some of the symptoms of depressed patients by blocking the formation of new fearful or emotional memories.

Previous studies have demonstrated that the expression of $\Delta \mathrm{FosB}$ is induced in the hippocampus by repeated antidepressant treatment, particularly ECS, and that the time course for this effect is consistent with the time course for the therapeutic action of antidepressant treatment (Hope et al, 1994). $\Delta$ FosB is also induced in the nucleus accumbens in response to repeated administration of cocaine and could contribute to the actions of psychostimulants and other drugs of abuse in this brain region 
a
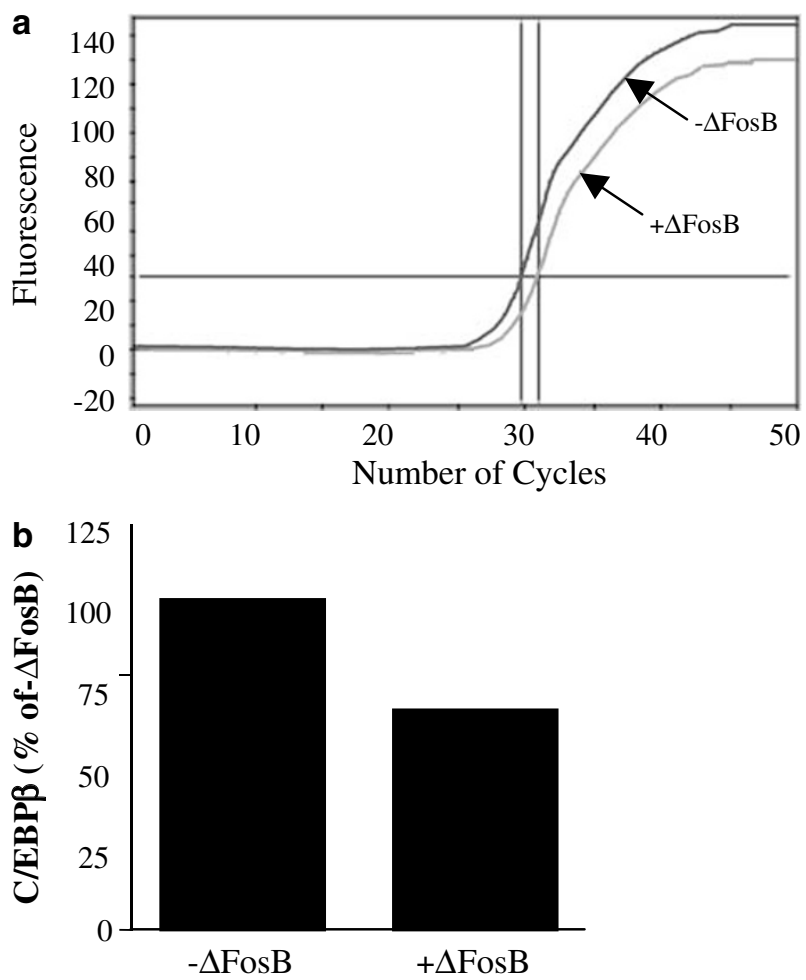

Figure 4 RT-PCR analysis of C/EBP $\beta$ mRNA levels in the hippocampus of inducible transgenic mice expressing $\Delta$ FosB. The C/EBP $\beta$ mRNA from the hippocampus of inducible transgenic mice expressing $\Delta \mathrm{FosB}(+\Delta \mathrm{FosB})$ or not expressing $\Delta$ FosB $(-\Delta$ FosB $)$ was quantified by real-time RT-PCR with specific primers for C/EBP $\beta$ and the fluorescent dye, sybre green. (a) The difference in cycle number at half of the exponential amplification between the RNA samples from $+\Delta$ FosB and $-\Delta$ FosB mice is shown. (b) The percentage of the C/EBP $\beta$ mRNA regulation in the inducible transgenic mice expressing $\triangle \mathrm{FosB}$ was calculated and was normalized to levels of cyclophilin. The results are presented as $\%$ of $-\Delta$ FosB and are the mean of four separate determinations.

(Nestler et al, 1999; Nestler, 2001). The inducible $\Delta$ FosB transgenic mice were developed to study further the molecular and cellular actions of this transcription factor and how they may relate to the actions of antidepressants and other psychotropic drugs. This approach is particularly appropriate because induction of $\Delta$ FosB after removal of doxycycline from the drinking water takes several weeks, similar to the time course for induction of $\Delta$ FosB by antidepressant treatment (Chen et al, 1998).

In the present study we have used a mouse cDNA microarray containing 4592 different genes to begin to characterize the gene expression profile that results from induction of $\triangle \mathrm{FosB}$ in the hippocampus. We have found that several different classes of genes, including protein kinases, receptors, transcription factors, ion channels, protein phosphatases, and proteases are regulated by induction of $\Delta$ FosB. One striking feature is that we consistently observed that regulated genes are decreased, not increased in the $\Delta$ FosB transgenic mice. This supports previous work demonstrating that $\Delta$ FosB can act as a transcriptional repressor because it lacks the C-terminus transactivation domain (Nakabeppu and Nathans, 1991; Nakabeppu et al, 1993). Additional studies will be required to confirm the regulation of these genes by
C/EBP $\alpha$ or $\beta$ mRNA

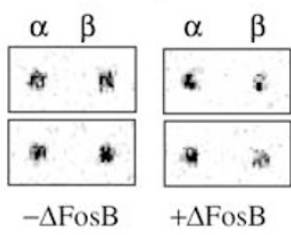

C

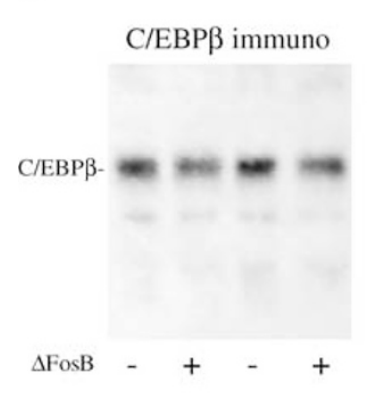

d

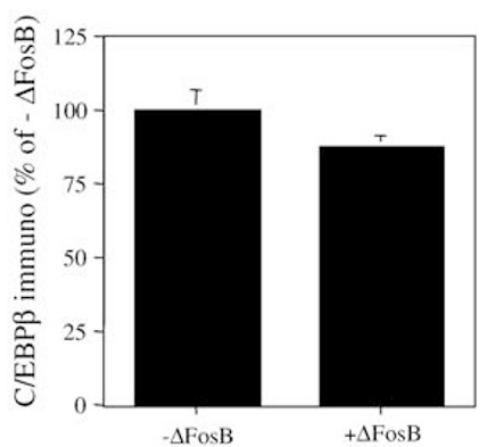

Figure 5 Analysis of the C/EBP $\beta$ mRNA and immunoreactivity in the hippocampus of inducible transgenic mice expressing $\triangle$ FosB. The C/EBP $\beta$ mRNA and immunoreactivity levels were determined by low-density dot blotting and Western blot, respectively. For comparison levels of the $\mathrm{CIEBP} \alpha \mathrm{mRNA}$ were also determined. Representative dot blots or immunoblots are shown in (a) and (c), respectively. The results of C/EBP $\beta$ and C/EBP $\alpha$ mRNA and C/EBP immunoreactivity in the transgenic mice expressing $\Delta$ FosB $(+\Delta$ FosB $)$ are presented in the bar graphs shown in (b) and (d), respectively. The results are presented as percent of $-\Delta$ FosB and are the mean \pm SEM, $n=4$ for dot blots and 3 for immunoblots. $* P<0.05$ compared to $-\Delta$ FosB. a

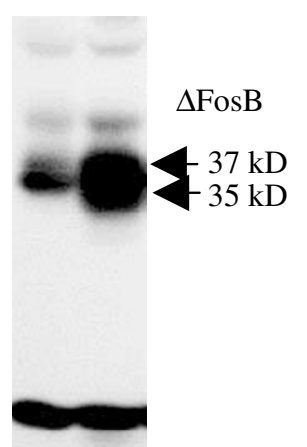

Sham ECS b

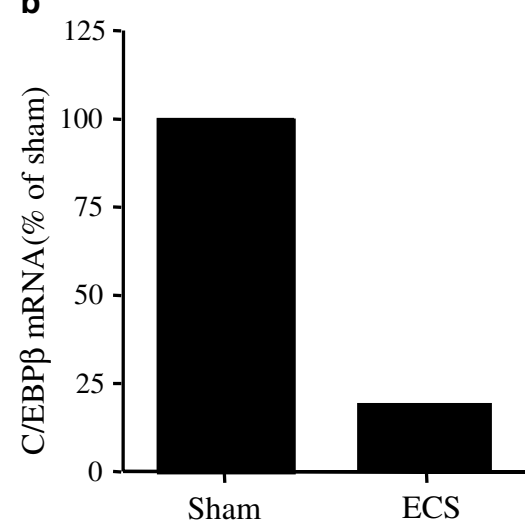

Figure 6 Chronic ECS treatment increases $\triangle F O S B$ and downregulates the $\mathrm{C} / \mathrm{EBP} \beta$ mRNA in the hippocampus. (a) Induction of $\Delta$ FosB immunoreactivity in the hippocampus of the rats receiving chronic ECS treatment was conducted by Western blot analysis. A representative Western blot is shown. (b) RNA samples from the hippocampus of the rats treated receiving chronic ECS or sham treatment were analyzed by realtime RT-PCR with specific primers for C/EBP $\beta$ (see Figure 4). The percentage of the C/EBP $\beta$ mRNA regulation in the ECS-treated rats was normalized to levels of cyclophilin. The results are presented as $\%$ of sham and are the means of four individual rat samples. 
$\Delta$ FosB using independent methods of analysis. In addition, it will be important to analyze other gene sets to characterize fully the targets that are regulated by $\Delta$ FosB in the hippocampus.

C/EBP $\beta$ was one of the most robustly regulated genes identified in the microarray studies (decreased by more than $70 \%$ ). In addition, decreased expression of C/EBP $\beta$ was confirmed by two independent methods, real-time RT-PCR and RNA dot blot in two separate groups of $\Delta$ FosB and littermate control mice. These results firmly establish that the $\mathrm{C} / \mathrm{EBP} \beta$ expression is downregulated in the hippocampus by the expression of $\Delta$ FosB. However, levels of C/EBP $\beta$ immunoreactivity were not significantly decreased in $\Delta$ FosB expressing transgenic mice, although there was a trend for a decrease. This suggests that the downregulation of the C/EBP $\beta$ mRNA does not result in a corresponding decrease in the levels of the $\mathrm{C} / \mathrm{EBP} \beta$ protein. Such an effect could be due to increased efficacy of mRNA translation or decreased degradation of the $\mathrm{C} / \mathrm{EBP} \beta$ protein. However, there are several additional possibilities that could lead to a functional outcome. For example, it is possible that the observed small decrease in $\mathrm{C} / \mathrm{EBP} \beta$ protein levels, although not significant, could result in decreased function of C/EBP $\beta$. It is also possible that $\mathrm{C} / \mathrm{EBP} \beta$ protein levels are decreased within certain cell layers or subtypes, for example the dentate gyrus granule cell layer of the CA3 pyramidal cell layers, and that the function of $C / \operatorname{EBP} \beta$ is reduced in these cell layers. Yet another possibility is that $\mathrm{C} / \mathrm{EBP} \beta$ is decreased within a particular subcellular compartment (ie nuclear fraction) and that this results in functional alterations. Additional studies will be required to determine the functional consequences of decreased C/EBP $\beta$ mRNA expression.

In addition to the downregulation of the $\mathrm{C} / \mathrm{EBP} \beta$ mRNA in $\Delta$ FosB-expressing transgenic mice, we found that chronic ECS treatment, which increases $\triangle$ FosB expression decreases levels of $\mathrm{C} / \mathrm{EBP} \beta$ in the hippocampus. This provides further evidence that $\Delta$ FosB acts as a repressor of the C/EBP $\beta$ expression. Downregulation of C/EBP $\beta$ does not appear to be unique to chronic ECS treatment. Other antidepressant treatments such as chronic exposure to fluoxetine are reported to downregulate the expression of C/EBP $\beta$ significantly (Patel and Lopez, 2001). While the effects of other chemical antidepressants must be evaluated in future investigations, it is possible that downregulation of $\mathrm{C} / \mathrm{EBP} \beta$ may be a common mechanism for antidepressant action.

To understand the molecular mechanisms by which $\Delta$ FosB downregulates $\mathrm{C} / \mathrm{EBP} \beta$, we analyzed the promoter region of the C/EBP $\beta$ gene for the presence of relevant regulatory elements. The $5^{\prime}$ flanking sequence of the $\mathrm{C} / \mathrm{EBP} \beta$ gene was obtained from the C57/BL6 mouse genome sequence database (UCSC Genome Bioinformatics Site). Analysis of the genomic DNA sequence revealed one AP-1 site (TGACgCA) and one CRE site (TGACGcAg) at the transcription initiation site, which are located 108 nucleotides upstream of the start codon (ATG) of the C/EBP $\beta$ gene. The AP-1 and CRE sites overlap, which suggests that $\triangle$ FosB could compete with CREB for the binding site and could thereby block the C/EBP $\beta$ gene transcription. Alternatively, $\Delta$ FosB could compete with other AP-1binding proteins that stimulate transcription. Future studies will be required to characterize the interaction of transcription factors at the AP-1 and CRE elements in the C/EBP $\beta$ gene promoter. This will be conducted using promoter-reporter assays in a transfected cell culture system. Another approach to determine if $\Delta$ FosB directly regulates $\mathrm{C} / \mathrm{EBP} \beta$ is to use null mutant mice that lack this transcription factor. $\Delta$ FosB is an alternative splice variant of FosB, and based on the hypothesis presented in this study we predict that ECS treatment would not result in downregulation of $\triangle \mathrm{FosB}$ in the FosB null mutants.

$\mathrm{C} / \mathrm{EBP} \beta$ belongs to a six-member family of transcription factors with structural homologies. The mechanisms by which the regulation of $\mathrm{C} / \mathrm{EBP} \beta$ could contribute to the actions of ECS and antidepressant treatment involve regulation of target genes that control learning and memory. The first indication that the C/EBP family of transcription factors may be involved in long-term memory came from studies in Aplysia (Alberini et al, 1994). In Aplysia, the C/EBP mRNA is induced rapidly by either serotonin or cAMP. Disruption of C/EBP in sensory neurons blocks long-term synaptic facilitation. Further studies in mammalian systems demonstrate that $\mathrm{C} / \mathrm{EBP} \beta$ is required for consolidation, but not reconsolidation, of long-term memory in an inhibitory avoidance learning task using electrical foot shocks (Taubenfeld et al, 2001). Blocking C/EBP $\beta$ with antisense oligonucleotides disrupts long-term memory of the fearful foot shock and reduces the latency for the animal to enter the dark compartment where it received the foot shock during training. One possible interpretation of the results of the present study is that downregulation of $\mathrm{C} / \mathrm{EBP} \beta$ may result in blockade of the formation of aversive and/or emotion-laden memories and thereby contribute to the therapeutic actions of antidepressants.

Analysis of other C/EBP family members has provided evidence that the actions of these transcription factors may be specific to fearful or aversive forms of memory. C/EBP $\delta$ null mutant mice exhibit enhanced contextual fear conditioning, but there is no effect on spatial memory or short-term contextual memory (Sterneck et al, 1998). The effect of $\mathrm{C} / \mathrm{EBP} \delta$ disruption on memory is different from that of C/EBP $\beta$ achieved with antisense oligonucleotides, as outlined above. However, these results may not be contradictory because different C/EBP proteins can have different functions (Lekstrom-Himes and Xanthopoulos, 1998). C/EBP dimerization is required for DNA binding, and different C/EBP proteins can heterodimerize with each other as well as with members of other families of transcription factors, leading to a wide range of transcriptional regulation from activation to repression (McKnight, 2001; Ramji and Foka, 2002). C/EBP $\delta$ has low affinity for the DNA-binding domain (LekstromHimes and Xanthopoulos, 1998), and may block the function of $\mathrm{C} / \mathrm{EBP} \beta$ by forming heterodimers with lower affinity to specific DNA-binding sites compared to C/EBP $\beta$ homodimers.

Depression and other mood disorders are complex illnesses that are most likely influenced by several different brain regions, including the amygdala, prefrontal cortex, and the hippocampus (Manji et al, 2001; Nestler et al, 2002). The hippocampus is highly sensitive to stress hormones, particularly adrenal-glucocorticoids that are increased by 
stressful stimuli and are often associated with depressive episodes (Duman et al, 2000; Manji et al, 2001). In addition, brain imaging studies have demonstrated a reduction of hippocampal volume in depressed patients (Manji et al, 2001; Nestler et al, 2002). Adaptations of the hippocampus could directly contribute to the cognitive abnormalities that are observed in depression, and could indirectly influence mood via connections with the amygdala and prefrontal cortex (Manji et al, 2001).

How C/EBP $\beta$ mediates the consolidation of long-term memory for aversive stimuli is still unknown. The inducible $\Delta$ FosB mice could serve as an additional genetic model for exploring the role of $\mathrm{C} / \mathrm{EBP} \beta$ in fear conditioning. Further studies in these areas might widen our knowledge of the long-term neural plasticity in response to fearful stimulation as well as provide information for the development of novel antidepressant medications.

\section{ACKNOWLEDGEMENTS}

This work was supported by USPHS grants MH45481 and 2 PO1 MH25642, a Veterans Administration National Center Grant for PTSD, and by the Connecticut Mental Health Center.

\section{REFERENCES}

Alberini CM, Ghirardi M, Metz R, Kandel ER (1994). C/EBP is an immediate-early gene required for the consolidation of longterm facilitation in Aplysia. Cell 76: 1099-1114.

Ang E, Chen J, Zagouras P, Magna H, Holland J, Schaeffer E et al (2001). Induction of nuclear factor-kappaB in nucleus accumbens by chronic cocaine administration. J Neurochem 79: 221-224.

Carew TJ, Sutton MA (2001). Molecular stepping stones in memory consolidation. Nat Neurosci 4: 769-771.

Chen AC, Shirayama Y, Shin KH, Neve RL, Duman RS (2001). Expression of the cAMP response element binding protein (CREB) in hippocampus produces an antidepressant effect. Biol Psychiatry 49: 753-762.

Chen J, Kelz MB, Hope BT, Nakabeppu Y, Nestler EJ (1997). Chronic Fos-related antigens: stable variants of deltaFosB induced in brain by chronic treatments. J Neurosci 17: 4933-4941.

Chen J, Kelz MB, Zeng G, Sakai N, Steffen C, Shockett PE et al (1998). Transgenic animals with inducible, targeted gene expression in brain. Mol Pharmacol 54: 495-503.

Chen J, Zhang Y, Kelz MB, Steffen C, Ang ES, Zeng L et al (2000). Induction of cyclin-dependent kinase 5 in the hippocampus by chronic electroconvulsive seizures: role of [Delta]FosB. J Neurosci 20: 8965-8971.

Conti AC, Cryan JF, Dalvi A, Lucki I, Blendy JA (2002). cAMP response element-binding protein is essential for the upregulation of brain-derived neurotrophic factor transcription, but not the behavioral or endocrine responses to antidepressant drugs. J Neurosci 22: 3262-3268.

Dowlatshahi D, MacQueen GM, Wang JF, Young LT (1998). Increased temporal cortex CREB concentrations and antidepressant treatment in major depression. Lancet 352: 1754-1755.

D'Sa C, Duman RS (2002). Antidepressants and neuroplasticity. Bipolar Disord 4: 183-194.

Duman RS (2002). Synaptic plasticity and mood disorders. Mol Psychiatry 7: S29-S34.

Duman RS, Heninger GR, Nestler EJ (1997). A molecular and cellular theory of depression. Arch Gen Psychiatry 54: 597-606.
Duman RS, Malberg J, Nakagawa S (2000). Neuronal plasticity and survival in mood disorders. Biol Psychiatry 48: 732-739.

Franco-Bronson K (1996). The management of treatmentresistant depression in the medically ill. Psychiatr Clin $\mathrm{N} \mathrm{Am}$ 19: $329-350$.

Hiroi N, Marek GJ, Brown JR, Ye H, Saudou F, Vaidya VA et al (1998). Essential role of the fosB gene in molecular, cellular, and behavioral actions of chronic electroconvulsive seizures. J Neurosci 18: 6952-6962.

Hope BT, Kelz MB, Duman RS, Nestler EJ (1994). Chronic electroconvulsive seizure (ECS) treatment results in expression of a long-lasting AP-1 complex in brain with altered composition and characteristics. J Neurosci 14: 4318-4328.

Kelz MB, Chen J, Carlezon Jr WA, Whisler K, Gilden L, Beckmann $\mathrm{AM}$ et al (1999). Expression of the transcription factor deltaFosB in the brain controls sensitivity to cocaine. Nature 401: 272-276.

Koch JM, Kell S, Hinze-Selch D, Aldenhoff JB (2002). Changes in CREB-phosphorylation during recovery from major depression. J Psychiatr Res 36: 369.

Lekstrom-Himes J, Xanthopoulos KG (1998). Biological role of the CCAAT/enhancer-binding protein family of transcription factors. J Biol Chem 273: 28545-28548.

Manji HK, Duman RS (2001). Impairments of neuroplasticity and cellular resilience in severe mood disorders: implications for the development of novel therapeutics. Psychopharmacol Bull 35: 5-49.

Manji H, Drevets WC, Charney DS (2001). The cellular neurobiology of depression. Nat Med 7: 541-547.

McKnight SL (2001). McBindall-a better name for CCAAT/ enhancer binding proteins? Cell 107: 259-261.

Nakabeppu Y, Nathans D (1991). A naturally occurring truncated form of FosB that inhibits Fos/Jun transcriptional activity. Cell 64: 751-759.

Nakabeppu Y, Oda S, Sekiguchi M (1993). Proliferative activation of quiescent Rat-1A cells by delta FosB. Mol Cell Biol 13: 4157-4166.

Nakagawa S, Kim JE, Lee R, Chen J, Fujioka T, Malberg J et al (2002). Localization of phosphorylated cAMP response elementbinding protein in immature neurons of adult hippocampus. J Neurosci 22: 9868-9876.

Nestler EJ (2001). Molecular basis of long-term plasticity underlying addiction. Nat Rev Neurosci 2: 119-128.

Nestler EJ, Barrot M, DiLeone RJ, Eisch AJ, Gold SJ, Monteggia LM (2002). Neurobiology of depression. Neuron 34: 13-25.

Nestler EJ, Kelz MB, Chen J (1999). DeltaFosB: a molecular mediator of long-term neural and behavioral plasticity. Brain Res 835: 10-17.

Newton SS, Chen J, Duman RS (2001). Microarray analysis of gene expression in mCREB inducible transgenic mice. Soc Neurosci Abstr 31: 113.

Nibuya M, Morinobu S, Duman RS (1995). Regulation of BDNF and trkB mRNA in rat brain by chronic electroconvulsive seizure and antidepressant drug treatments. J Neurosci 15: 7539-7547.

Nibuya M, Nestler EJ, Duman RS (1996). Chronic antidepressant administration increases the expression of cAMP response element binding protein (CREB) in rat hippocampus. $J$ Neurosci 16: 2365-2372.

Patel PD, Lopez JF (2001). Regulation of hippocampal CCAAT/ enhancer binding protein BETA (C/EBP) mRNA in rats by antidepressant medications. Soc Neurosci Abstr 31: 22.

Ramji DP, Foka P (2002). CCAAT/enhancer-binding proteins: structure, function and regulation. J Biochem 365: 561-575.

Sterneck E, Paylor R, Jackson-Lewis V, Libbey M, Przedborski S, Tessarollo L et al (1998). Selectively enhanced contextual fear conditioning in mice lacking the transcriptional regulator 
CCAAT/enhancer binding protein delta. Proc Natl Acad Sci USA 95: 10908-10913.

Stewart CA, Reid IC (2000). Repeated ECS and fluoxetine administration have equivalent effects on hippocampal synaptic plasticity. Psychopharmacology (Berl) 148: 217-223.

Taubenfeld SM, Milekic MH, Monti B, Alberini CM (2001). The consolidation of new but not reactivated memory requires hippocampal C/EBPbeta. Nat Neurosci 4: 813-818.
Thome J, Sakai BM, Shin KH, Steffen C, Zhang Y-J, Impey S et al (2000). cAMP response element-mediated gene transcription is upregulated by chronic antidepressant treatment. J Neurosci 20: 4030-4036.

Winston S, Hayward MD, Nestler EJ, Duman RS (1990). Chronic electroconvulsive seizures down regulate expression of the c-fos and c-jun proto-oncogenes in rat cerebral cortex. J Neurochem 54: 1920-1925. 